\title{
ISOLATION OF LACTIC ACID BACTERIA FROM MALAYSIAN NON-BROILER CHICKEN (GALLUS GALLUS) INTESTINE WITH POTENTIAL PROBIOTIC FOR BROILER FEEDING
}

\author{
Tengku Haziyamin Tengku Abdul Hamid and Ezureen Ezani \\ Department of Biotechnology, Kulliyyah of Science, \\ International Islamic University Malaysia, Kuantan Campus, Jalan Istana, \\ Bandar Indera Mahkota, 25200, Kuantan, Pahang, Malaysia.
}

haziyamin@iium.edu.my

ABSTRACT: Probiotic supplement can function as substitute for antibiotics especially in the broiler chicken feeding which can form an integral part of organic farming. Broiler forms one of an important protein source in South East Asia. Lactic acid bacteria (LAB) are important inhabitants of animal intestine and are useful source of probiotic microorganisms. Non-broiler chicken could be an ideal source of probiotic microorganisms that can be utilized for large scale broiler feeding. Our studies have successfully identified, through morphological and biochemical tests, 11 LAB isolates from gastrointestinal tract of local non-broiler chicken (Gallus gallus). These isolates have the ability to utilize lactose as part of their metabolism process and all showed negative reactions on catalase test. Out of the eleven (11) isolates, three (3) isolates were Gram-positive cocci and remaining isolates were of Gram-positive bacilli. Three isolates (E4, E11 and E17) showed at least $10 \mathrm{~mm}$ inhibitory effects on disc diffusion test against pathogenic bacteria Salmonella typhimurium. The partial 16S rRNA gene sequencing showed that one isolate (E17) has 89\% similarity with Lactobacillus rhamnosus. These LAB strains isolated from Malaysian domestic non-broiler chicken gastrointestinal tract can potentially be used as a component for probiotics formulation in poultry feeding.

ABSTRAK: Makanan tambahan probiotik boleh berfungsi sebagai pengganti antibiotik terutamanya dalam pemakanan ayam pedaging yang akan membentuk bahagian kamiran dalam penternakan organik. Ayam pedaging merupakan sumber protein penting di Asia Tenggara. Bakteria asid laktik (lactic acid bacteria $(L A B)$ ) merupakan penghuni penting dalam usus haiwan dan merupakan sumber penting dalam mikroorganisma probiotik. Ayam bukan pedaging sesuai dijadikan sumber mikroorganisma probiotik agar dapat digunakan sebagai pemakanan ayam pedaging secara besar-besaran. Kajian telah berjaya mengenal pasti, melalui kaedah morfologi dan uji kaji biokimia, 11 LAB diasingkan daripada salur gastrousus ayam bukan pedaging (Gallus gallus). Pencilan ini berupaya menggunakan laktosa sebagai sebahagian daripada proses metabolisma dan semuanya menunjukkan kesan negatif terhadap ujian katalase. Daripada sebelas (11) pencilan, tiga (3) pencilan adalah kokus gram-positif dan pencilan yang lainnya adalah basilus grampositif. Tiga pencilan (E4, E11 dan E17) menunjukkan sekurang-kurangnya $10 \mathrm{~mm}$ kesan rencatan terhadap ujian resapan cakera terhadap bakteria patogen Salmonella typhimurium. Sebahagian daripada urutan gen 16S rRHA menunjukkan bahawa satu pencilan (E17) mempunyai 89\% persamaan dengan Lactobacillus rhamnosus. Strain LAB ini diasingkan daripada salur gastrousus ayam tempatan bukan pedaging, sesuai digunakan sebagai komponen untuk rumusan probiotik dalam pemakanan ayam-itik.

KEYWORDS: lactic acid bacteria; probiotic; non-broiler chicken; Lactobaccilus rhamnosus 


\section{INTRODUCTION}

The variable use of probiotics as a daily supplement has become a popular routine in commercial poultry feeding, particularly following antibiotic treatment. Lactic acid bacteria or LABs are the most common microbes employed as probiotics and these strains are usually of Lactobacillus sp, Bifidobacterium sp and Enterococcus sp [1]. Two principal kinds of probiotic bacteria, the members of the genera Lactobacillus and Bifidobacterium, have been studied in detail [2]. These are Gram-positive lactic acidproducing bacteria that constitute a major part of the normal intestinal microflora in animals and humans. These friendly bacteria play key role in enhancing the resistance to colonization by potentially pathogenic organisms in the gut. Bacterial food-borne diseases in chicken are the major problem affecting the productivity in poultry industry. Commonly, the control of this disease is based on the administration of antibiotics. Meanwhile, the use of antibiotic as growth promoter is so extensive in poultry and pig industries $[3,4]$. However, such treatment could develop resistant bacteria [5,6] and result in antibiotic residues leftover in chicken which is a potential hazard to public health. Furthermore, the normal microflora which is beneficial to chicken may also be killed or inhibited due to the administration of antibiotics [7] and a new approach of using probiotic is gaining acceptance [8]. In the recent years, there are great interests in the use of probiotic in poultry feeding to improve disease resistance and growth performance. Probiotic bacteria competed with the pathogen for nutrient, stimulated the immune system [7] and showed good colonizing and antagonistic properties against the pathogens [9].

However, the proper probiotic supplements are relatively expensive, and different studies have used different plethora of LAB species and strains. In some countries, successful probiotic supplement could be subjected to trade secret and consequently, commercially available probiotics formulation may not contain the most appropriate strains or doses. As a result, the extensive use of probiotic is not quantitative and economically ineffective at the larger scale. Due to the LAB diversity and poorly understood interactions between the microbes and intestine, determining the correct types and quantity of probiotics are the biggest challenge [10]. Non-broiler chicken could be a good source of probiotic for broiler feeding. Malaysian non-broiler chicken referred as 'ayam kampung' is usually fed with household foods, and these are usually free of antibiotic. In this work, LAB strains from the intestinal tissue of non-broiler chickens were screened and characterized. It is hope that the isolated LAB can potentially be used as supplement to the young or growing broiler.

\section{MATERIALS AND METHODS}

A selected non-broiler chicken was slaughtered and it intestinal tissues was dissected and collected. The intestinal tissue was cut and suspended into $5 \mathrm{ml}$ phosphate buffered saline PBS buffer and briefly vortexed. The tissue was grinded until homogenised and the solution kept as a stock. This was serially diluted in PBS and each dilution was plated on MRS agar followed by incubation at $37{ }^{\circ} \mathrm{C}$ overnight, anaerobically. MRS broth and media contained $1.0 \%$ peptone, $0.8 \%$ meat extracxt, 0.4 yeast extract, $2.0 \%$ glucoase, $0.5 \%$ sodium acetate, $0.1 \%$ Tween $80,0.2 \%$ dipotassium hydrogen phosphate, $0.2 \%$ triammonium citrate, $0.02 \%$ magnesium sulfate and $0.005 \%$ manganese sulfate. Single colonies were sub-cultured and kept in $80 \% \mathrm{v} / \mathrm{v}$ glycerol and stored at $-80^{\circ} \mathrm{C}$ for future identification processes. Gram staining, lactose utilization test, catalase tests were carried 
out on the selected colonies. In lactose utilization test, lactose and few drops of bromocresol purple was added into nutrient agar (NA).

Genomic DNAs were extracted from 11 isolated lactic acid bacteria strain. DNA was extracted using method as outlined in the protocol on DNeasy® Blood and Tissue Extraction Kit (QIAGEN). The 16S ribosomal gene was amplified by PCR using the universal primers $\mathrm{pA}$ forward (5'-AGAGTTTGATCCTGGCTCAG-3') and $\mathrm{pE}$ reverse (5'CCGTCAATTCCTTTGAGTTT-3'). The PCR products were then loaded in $1.0 \%$ agarose gel for electrophoresis and visualized on under UV transilluminator.

For detection of antimicrobial activity, a disc diffusion method was used. Sterile filter discs $(12 \mathrm{~mm})$ were dipped into the culture broth (MRS broth) of lactic acid bacteria, incubated for 42 hours and placed on solidified nutrient agar NA (OXOID) which was seeded with 12 to 14 hours cultures of Salmonella typhimurium (pathogenic bacteria). The plates were stored at $4{ }^{\circ} \mathrm{C}$ for 3 to 4 hours to permit diffusion, and finally incubated at $37{ }^{\circ} \mathrm{C}$ for 14 to 16 hours. Disc dipped in uninoculated MRS broth was served as control. Zones of inhibition observed were then measured [11, 12]. Disk impregnated in $0.4 \mathrm{mg} / \mathrm{ml}$ Streptomycin was taken as control.

\section{RESULTS AND DISCUSSION}

All isolates appeared positive in lactose utilisation test. These bacteria were able to ferment lactose to produce lactic acid that lowers the $\mathrm{pH}$ of the media that, in turn, changed the purple indicator dye to yellow indicative of fermentation activities (Fig. 1a). Gram reaction and morphology studies showed that out of eleven (11) isolates, three (3) isolates were Gram-positive bacilli and eight (8) isolates were Gram-positive cocci (Table 1 and Fig. 1b). In the antimicrobial test, all eleven (11) isolates produced antimicrobial compound that were active against pathogenic bacteria Salmonella typhimurium strains. This was indicated by the formation of clear inhibitory zones near the diffusion spots (Fig. 2). As also shown in Table 1, sample E4, E11 and E17 produced more that $10 \mathrm{~mm}(12-15 \mathrm{~mm})$ diameter zones of inhibition; while all other samples produced less than $10 \mathrm{~mm}$ zone of inhibitions. Several factors could cause these inhibitions. Other than the production of organic acid, the antagonistic activity of LAB towards pathogens was also due to the production of bactericidal substances like bacteriocins [1].

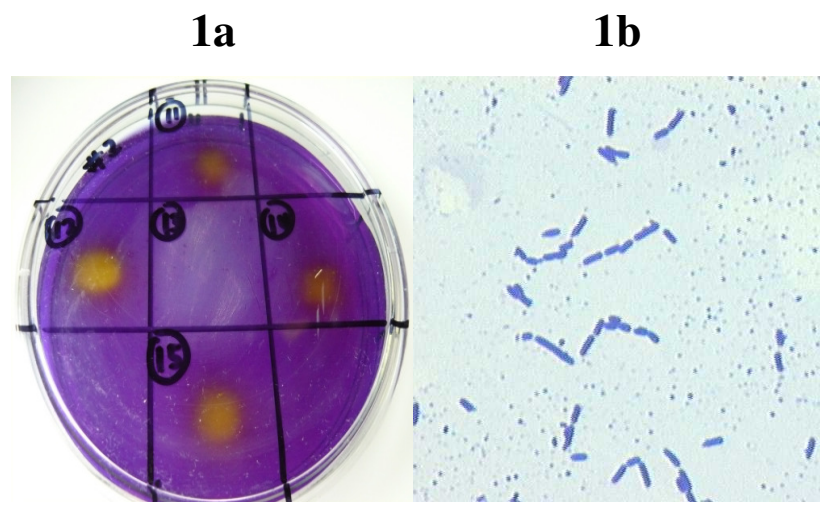

Fig. 1: a) Lactic acid bacteria changed the agar from purple to yellow indicative for lactic acid fermentation and formation of lactate;

b) Morphology and gram staining of isolate 17 showing gram positive coccobacilli (oil immersion, 1000x magnification). 
Table 1: Biochemical and morphological test for isolates from chicken intestine.

\begin{tabular}{cccccc}
\hline Isolates & $\begin{array}{c}\text { Gram } \\
\text { Reaction }\end{array}$ & Shape & Catalase & Lactose & $\begin{array}{c}\text { Zone of } \\
\text { inhibition* }\end{array}$ \\
\hline E2 & + & Cocci & - & + & + \\
E4 & + & Cocci & - & + & ++ \\
E10 & + & Bacilli & - & + & + \\
E11 & + & Cocci & - & + & ++ \\
E12 & + & Cocci & - & + & + \\
E14 & + & Cocci & - & + & + \\
E15 & + & Cocci & - & + & + \\
E17 & + & Bacilli & - & + & ++ \\
E18 & + & Cocci & - & + & + \\
E19 & + & Cocci & - & + & + \\
E24 & + & Bacilli & - & + & + \\
\hline
\end{tabular}

*Using Salmonella thyphimurium as indicator

$+<$ less than $10 \mathrm{~mm}$

$++>$ more than $10 \mathrm{~mm}$

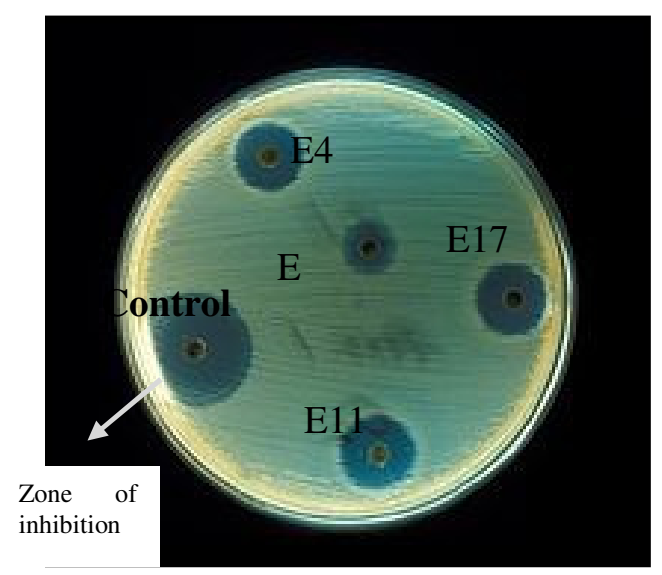

Fig. 2: Lactic acid bacteria against Salmonella typhimurium strains in disk diffusion method. Zone of inhibitions form surrounding the disk impregnated with sample LAB cultures E4, E11, E24 and E17.

As shown in Table 2, the result ribosomal rRNA sequence from one of the sample (isolate E17) produced $1.5 \mathrm{~kb}$ fragment (Fig. 3). The sequence indicated $89 \%$ similarity to Lactobacillus rhamnosus GG (ATCC 53103) (Table 2). The other closely similar sequences were Lactobacillus plantarum followed by other common LAB, Lactobacillus casei and others. Lactobacillus rhamnosus GG was isolated from healthy human intestinal tract. This strain has however, established clinical health effects to human that prevents urogenital tract infection from pathogens, human diarrhea [13-15] and respiratory infections risk in children 
[16]. It was shown that a strong antimicrobial activity of Lactobacillus rhamnosus GG against Salmonella typhimurium is due to the accumulation of lactic acid produced [17]. The usefulness of Lactobacillus rhamnosus strain in formulating probiotic feeding was previously suggested [1].

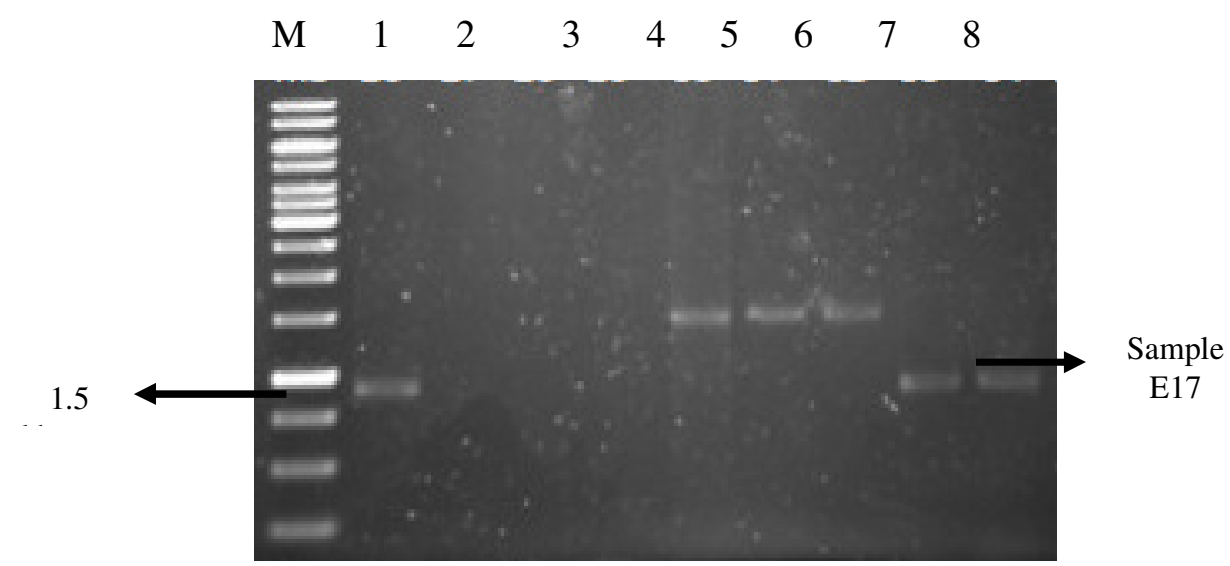

Fig. 3: The polymerase chain reaction amplification of ribosomal RNA gene using rRNA universal primer. Lane $\mathrm{M}$ in $1 \mathrm{~kb}$ ladder (Fermentas).

Lane number 1 to 9 correspond to genomic sample from the 9 of the isolates, of which lane 9 is for isolate E17.

Table 2: The NCBI BLAST hit list for rRNA sequence from Sample E17 isolate.

\begin{tabular}{llrr}
\hline \multicolumn{1}{c}{ Strain from NCBI databse } & \multicolumn{1}{c}{ Reference } & Score & E-value \\
\hline Lactobacillus rhamnosus GG & NC 013198.1 & 477 & $1 \mathrm{e}-133$ \\
Lactobacillus plantarum & NZ ACGZ01000098.1 & 473 & 2e-132 \\
Lactobacillus plantarum JDM1 & NC 012984.1 & 473 & 2e-132 \\
Lactobacillus plantarum wcfS1 & NC 004567.1 & 472 & $6 \mathrm{e}-132$ \\
Lactobacillus rhamnosus LMS2-1 & NZ ACIZ01000148.1 & 472 & $6 \mathrm{e}-132$ \\
Lactobacillus rhamnosus HN001 & NZ ABWJO1000068.1 & 472 & $6 \mathrm{e}-132$ \\
Lactobacillus rhamnosus Lc705 & NC 013199.1 & 472 & $6 \mathrm{e}-132$ \\
Lactobacillus casei BL23 & NC 010999.1 & 472 & $6 \mathrm{e}-132$ \\
Lactobacillus casei ATCC334 & NC 008526.1 & 472 & $6 \mathrm{e}-132$ \\
Lactobacillus salivarius ATCC 11741 & NC 007929 & 459 & $5 \mathrm{e}-128$ \\
Lactococcus lactis KF 147 & NC 013656.1 & 361 & $1 \mathrm{e}-98$ \\
\hline
\end{tabular}

\section{CONCLUSION}

In this work, we have successfully isolated lactic acid bacteria (LAB) strain from the gastrointestinal tract of Malaysian domestic non-broiler chicken. This isolated bacteria demonstrated common probiotic properties. Out of 25 isolates, 11 isolates have the ability to utilize lactose as part of their metabolism process, all showed negative reactions towards 
catalase test and active against pathogenic bacteria Salmonella typhimurium. Three out of the 11 isolates were Gram-positive cocci and remaining 8 isolates were Gram-positive bacilli. Based on ribosomal RNA sequencing, one of the isolated bacilli have $89 \%$ similarity to Lactobacillus rhamnosus. While this strain was established it uses as probiotic in yogurt and dairy product, it was also shown to be pathogenic in some other circumstances. From this study, the isolated strains could potentially be used as probiotics in poultry feeding formulation.

\section{ACKNOWLEDGEMENT}

The authors wish to thank International Islamic University Malaysia for financial assistance in this work (IIUM Endownment Fund, EDW B0905-282).

\section{REFERENCES}

[1] Karimi Torshizi M. A., Rahimi Sh., Mojgani N., Esmaeilkhanian S. and Grimes J. L.. Screening of indigenous strains of lactic acid bacteria for development of a probiotic for poultry. Asian-Aust. J. Anim. Sc. 2008 21(10); 1495 - 1500

[2] Tannock, G. (2005). Probiotics and Prebiotics: Where are we going? Norfolk, UK: Caister Academic Press.

[3] Celik K, Okan F, and Denli M. Effect of dietary probiotic, organic acid and antibiotic supplementation to diet on broiler performance and carcass yield. 2003. Pak. J. Nutr., 2(2): 8991

[4] Charles, OW and Duke, S. The response of laying hens to dietary fermentation products and probiotic-antibiotic combinations. Poultry Sci. 57: 1125

[5] Langhout P (2000). New Additives for broiler chickens, 1978. Feed Mix. 18(6); 24-27

[6] Stavric S., B. Buchanan, and T.M. Gleeson. Intestinal colonization of young chicks with Escherichia coli O157:H7 and other verotoxin-producing serotypes. 1993. J. Appl. Bacteriol. 74:557-563.

[7] Edelman S., B. Westerlund-Wikstrom, S. Leskela, H. Kettunen, N. Rautonen, J. Apajalahti, and T. K. Korhonen. (2002). In vitro adhesion specifity of indigenous Lactobacilli within the avian intestinal tract 2001. Appl. Environ. Microbiol. 68:5155-5159.

[8] Reid, G.. The scientific basis for probiotic strains of Lactobacillus. 1999. Appl. Environ. Microbiol. 65:3763-3766.

[9] Aswathy, R. G., Ismail B., John R. P., Nampoothiri K. M. Evaluation of the probiotic characteristics of newly isolated lactic acid bacteria. 2008. Appl Biochem Biotechnol. 151:244-55.

[10] Britt, R. R.. Bacteria vs. bacteria: The New Fight against Salmonella. Retrieved on August 27, 2009, from http://www.livescience.com/health/060317_good_bacteria.html.

[11] Apella, M.C., Gonzalez, S.N., Nader de Macias, M.E., Romero, N. \& Oliver, G. . In vitro studies on the inhibition of the growth of Shigella sonnei by Lactobacillus casei and Lactobacillus acidophilus. 1992. J. Appl. Bacteriol., 73, 480-483.

[12] Hamadan, J. \& Mikolajcik, E.M. Acidolin: an antibiotic produced by Lactobacillus acidophilus. 1974. J. Antibiot., 27, 631-636.

[13] Canaani, R. B.; Cirillo, P., Terrin, G., Cesarano, L., Spagnuolo, M. I., De Vincenzo, A., Albano, F., Passariello, A., De Marco, G., Manguso, F., Guarino, A. Probiotics for treatment of accute diarrhoea in children: randomised clinical trial of five different preparations. 2007. Brit. Med. J. 335 (7615): 340.

[14] Österlund, P., Ruotsalainen, T., Korpela, R., Saxelin, M., Ollus, A., Valta, P., Kouri, M., Elomaa, I., Joensuu, H.. Lactobacillus supplementation for diarrhoea related to chemotherapy of colorectal cancer: a randomised study. 2007. Brit. J. Cancer. 97 (8): 1028-34.

[15] Guandalini, Pensabene, L., Zikri, M. A., Dias, J. A., Casali, L. G., Hoekstra, H., Kolacek, S., Massar, K., Micetic-Turk, D., Papadopoulou, A., de Sousa, J. S., Sandhu, B., Szajewska, H., 
IIUM Engineering Journal, Vol. 12, No. 4, 2011: Special Issue on Biotechnology

Haziyamin and Ezureen

Weizman, Z. Lactobacillus GG administered in oral rehydration solution to children with acute diarrhea: a multicenter European trial. 2000. J. Pediatr. Gastroenterol. Nutr. 30 (1): 5460.

[16] Hatakka, Savilahti, E., Pönkä, A., Meurman, J. H., Poussa, T., Näse, L., Saxelin, M., Korpela, $\mathrm{R}$. Effect of long term consumption of probiotic milk on infections in children attending day care centres: double blind, randomised trial. 2001. Brit. Med. J. 22 (7238): 1327.

[17] Sigrid C.J. De Keersmaecker, Tine L.A. Verhoeven, Jos Desair, Kathleen Marchal, Jos Vanderleyden, and István Nagy. Strong antimicrobial activity of Lactobacillus rhamnosus GG against Salmonella typhimurium is due to accumulation of lactic acid. 2006. Microbiol. Lett. 256 (1): 89-96 